\title{
An Analysis of Energy Production of Rooftop on Grid Solar Power Plant on A Government Building (A Case Study of Setjen KESDM Building Jakarta)
}

\begin{tabular}{l}
\hline Received \\
11 April 2020 \\
Revised \\
20 may 2020 \\
\\
Accepted for Publication \\
01 July 2020 \\
Published \\
17 July 2020
\end{tabular}

\author{
Zulkiflii $^{1^{*}}$,W Wilopo ${ }^{1}$, and K Ridwan ${ }^{1}$ \\ 1. Department of System Engineering, Faculty of Engineering, Universitas Gadjah Mada, $3^{\text {rd }}$ \\ Teknika Utara Street, Yogyakarta, 55281, Indonesia. \\ *Email: zulkifli84@mail.ugm.ac.id
}

\begin{abstract}
In producing electrical energy, the solar module is affected by some factors, such as the solar radiation intensity, temperature, orientation and slope of the module, and shading that occurs during operation. The solar power plant of Setjen KESDM is coordinated at $6^{\circ} 10^{\prime} 53.73^{\prime \prime}$ south latitude and $106^{\circ} 49^{\prime} 24.61^{\prime \prime}$ east longitude, with a slope of $9.7^{\circ}-10.0^{\circ}$ and azimuth of $-2.0^{\circ}$ to $-5.0^{\circ}$ towards the north. It consists of five placement locations, including $11^{\text {th }}$ floor rooftop, T1, T2, T3, and L carports with a total capacity of $150 \mathrm{kWp}$. The analysis of the production of rooftop on grid solar power plant in the government building with a case study in the Setjen KESDM was intended to determine the level of production of the solar power plant built and the parameters that influence it, which was conducted by comparing the real results with the simulation results using SAM software. The energy production in 2017 was $118,259.3 \mathrm{kWh}$, in 2018 was 106,318.3 kWh, and in 2019 was 109,973.0 kWh. The highest production was obtained in September, October, and March every year due to the maximum solar radiation. The solar power plant on the $11^{\text {th }}$ floor rooftop was more maximal in producing energy for all positions of the sun than the solar power plant on the T1, T2, T3, and L carports because it was free of shading from buildings and trees. The output produced by the solar power plant of Setjen KESDM could not reach the maximum point because the location temperature was higher than the standard test conditions of the solar module.

Keywords: Rooftop, production, declination, temperature, shading.
\end{abstract}

\section{Introduction}

Based on the target of the General Plan for National Energy, the utilization of new and renewable energy is set at $45.153 \mathrm{GW}$ or $23 \%$ in 2025 , with a composition of hydropower plant of $18.0 \mathrm{GW}$, geothermal power plant of $7.2 \mathrm{GW}$, mini-hydropower plant and micro-hydropower plant of $3.0 \mathrm{GW}$, bioenergy power plant of $5.5 \mathrm{GW}$, wind farm of $1.8 \mathrm{GW}$, solar power plant of $6.5 \mathrm{GW}$, and other new and renewable energy power plant of $3.1 \mathrm{GW}$ [1]. The growth rate of rooftop solar power plant use increased significantly. Based on data, there were 1,435 PLN customers using rooftop on grid solar power plant up to September 2019. In contrast, there were only 609 customers previously in January 2019 or there was an increase of $181 \%$ since the enactment of the Regulation of the Minister of Energy and Mineral Resources Number 49 of 2018 containing the import-export scheme with a respective composition of $65 \%$ and $35 \%$ [2]. This is also supported by the geography of Indonesia, which is an area with stable radiation intensity throughout the year with a radiation intensity of $4.8 \mathrm{kWh} / \mathrm{m}^{2}$ [3].

In producing electrical energy, the solar module is affected by some factors, such as the solar radiation intensity, temperature, orientation and slope of the module, and shading that occurs during operation [4], [5]. In good weather during the day, radiation can reach $1,000 \mathrm{~W} / \mathrm{m}^{2}$ on the surface of the earth. On some cloudy and sunny days, solar radiation is reflected through the clouds, so that sometimes insolation can reach up to $1,400 \mathrm{~W} / \mathrm{m}^{2}$ in the short term [6], [7]. 


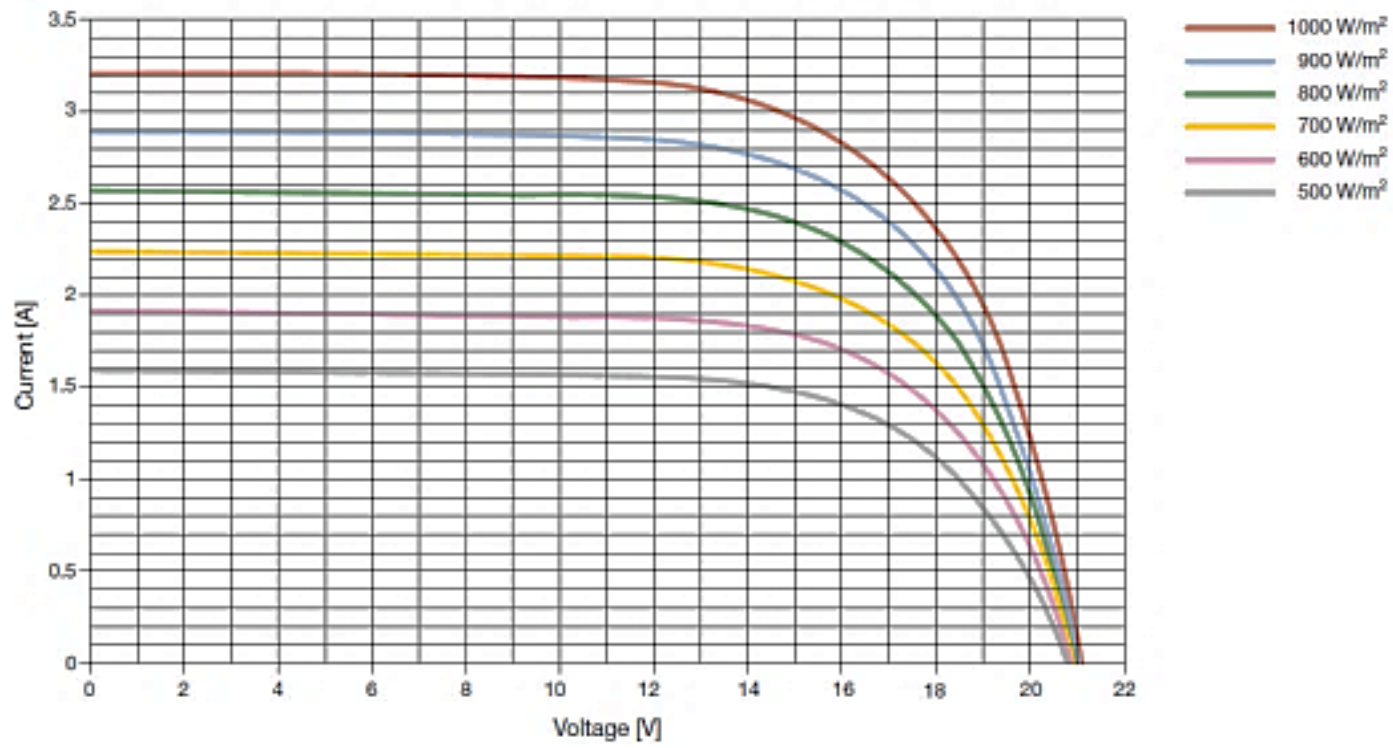

Figure 1. Graph of function I and V towards solar radiation.

Based on Figure 1, it can be seen that changes in radiation will affect the current generated by the solar module, while the voltage looks almost constant [5]. The operating temperature of the solar module is the second major factor affecting the performance of the solar module, following the amount of solar radiation [8]. A solar module will work best under Standard Test Conditions (STC), in which the solar radiation is $1,000 \mathrm{~W} / \mathrm{m}^{2}$, wind speed is about $1 \mathrm{~m} / \mathrm{s}$ (air mass of 1.5) and the ambient temperature is $25^{\circ} \mathrm{C}$. The higher the ambient temperature around the solar panel, the less electrical power produced (Figure 2) [9], [10].

Based on a study, thin film solar panels are affected by temperature with a temperature coefficient of $-0.0984 \%,-0.1090 \%$, and $-0.1240 \%$ for monocrystals and polycrystals [11]. Electric power for copper indium gallium selenide module technology has the lowest power reduction (with an average percentage reduction in power of $0.38 \% /{ }^{\circ} \mathrm{C}$ ). In comparison, the monocrystalline module has the highest power reduction (with an average percentage reduction in power of $0.54 \% /{ }^{\circ} \mathrm{C}$ ), while the polycrystalline module has a power reduction percentage of $0.49 \% /{ }^{\circ} \mathrm{C}[12]$.

Changes in the temperature of solar cells are affected by location temperature, cloud conditions, and wind velocity in the environment around the solar panel placement area [13]-[15]. In addition to the effect of ambient temperature, electromagnetic radiation absorbed by solar panels can also increase the temperature of solar cells [16].

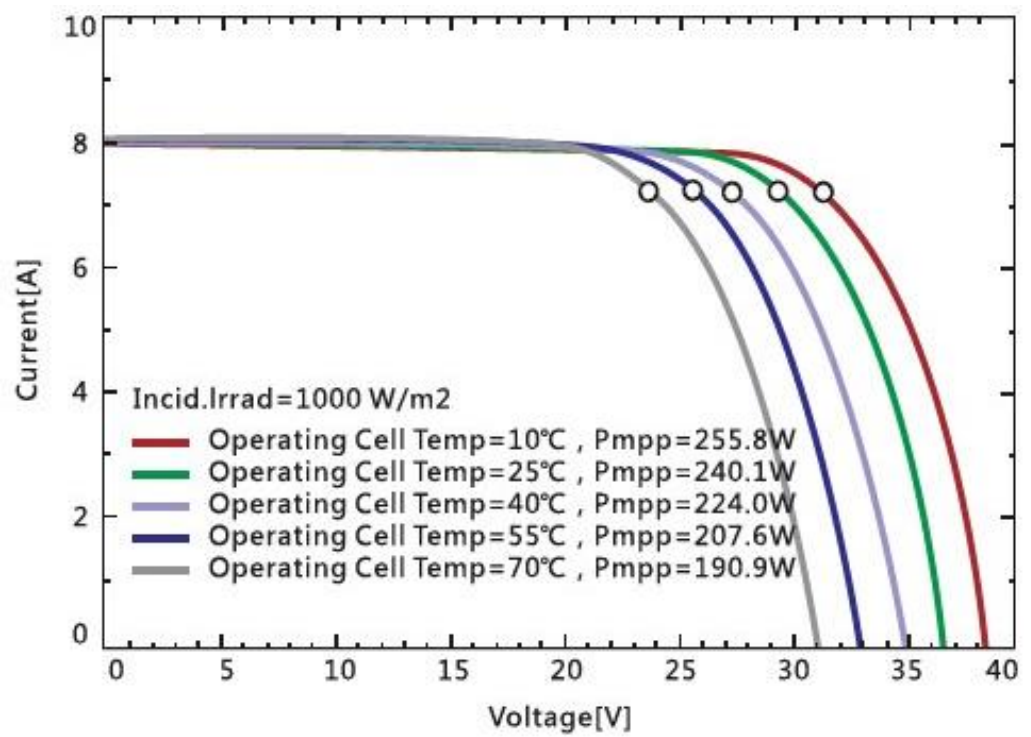

Figure 2. Graph of function I and V towards temperature. 


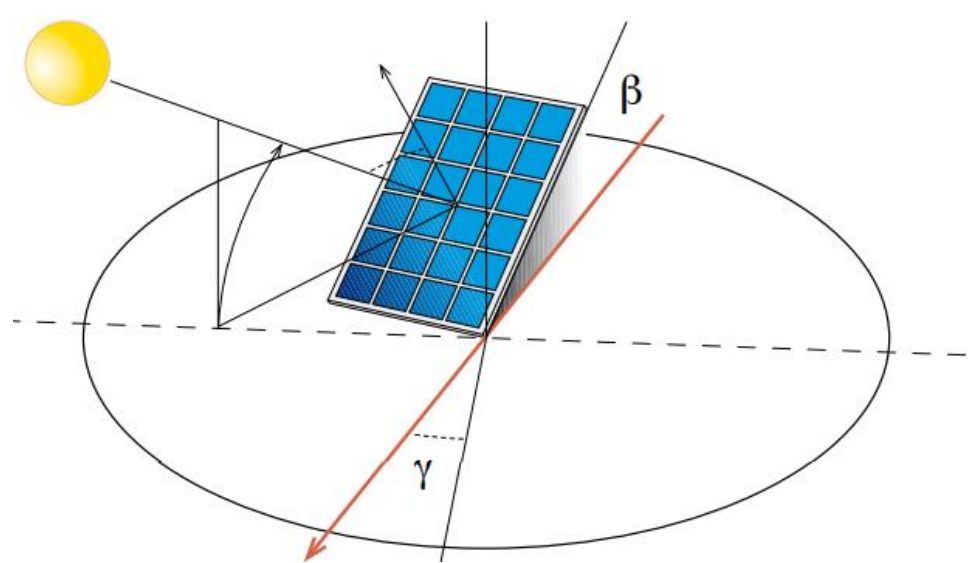

Figure 3. Optimal position of solar module placement.

To obtain the maximum photovoltaic output, one of the methods is by optimizing the absorption of solar radiation. This can be done by positioning the angle of the sun's rays to always be $90^{\circ}$ (Figure 3 ) to the solar module, also if possible, at the varied sun position according to latitude and solar declination when the axis of rotation of the earth is tilted around $\pm 23.45^{\circ}$ (Figure 4) [5]. The orientation of the panel can be indicated by azimuth angle $(\gamma)$, the deviation concerning the optimal direction to the north, the slope angle $(\beta)$, is the angle of the panel to the horizontal plane.

A previous study [17] on the optimization of the tilt angle of the solar collector in Surabaya stated that in March to September, the optimum tilt angle of the module ranges from $0^{\circ}$ to $40^{\circ}$ to the north, while in October to March, the optimum angle of the module ranges from $0^{\circ}$ to $30^{\circ}$ to the south. The results of another study [18] in Southeast Sulawesi showed that the configuration of solar technology with an optimal monthly panel angle adjustment could increase the annual energy produced by $10 \%$, compared to the fixed panel angle method. Besides, the geographical position of an area is crucial for optimizing the direction of the azimuth and tilt angle of the solar panel [19].

Solar power plant installation must consider the area that will be placed for the solar module. The location must be free from trees, leaf litter, buildings, clouds, or by solar modules installed nearby that can cause partial shading. Solar cells that consist of P-N junctions will stop producing energy and become a passive load when shaded by objects. These cells will function as diodes that block the current produced by other solar cells connected in series [20], [21]. Some studies assumed that the reduction in energy production (Figure 5) is in line to the area experiencing shading and the reduction in solar radiation, the decrease in power at the module or array level is often far from linearity with the part experiencing shading [20], [22], [23].

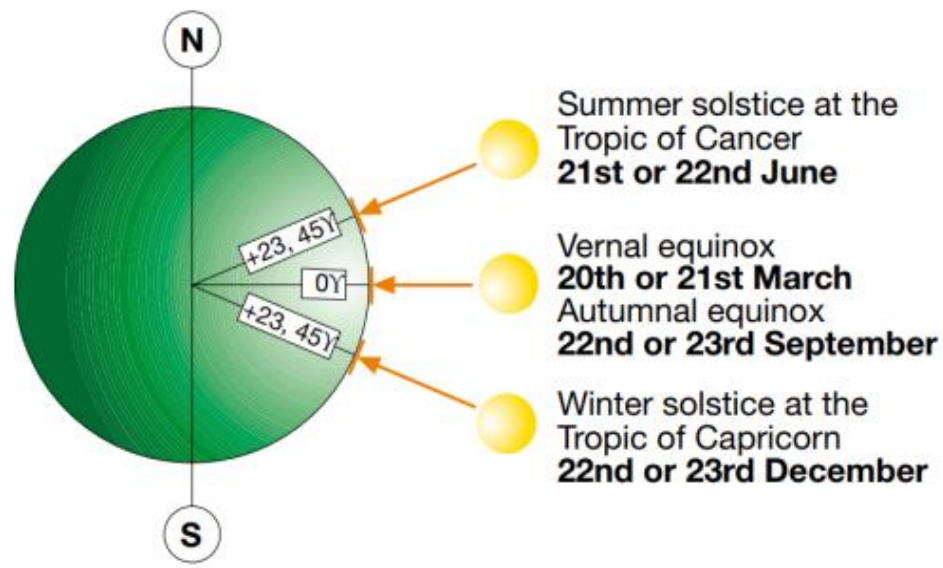

Figure 4. Changes in solar declination angle in one year. 


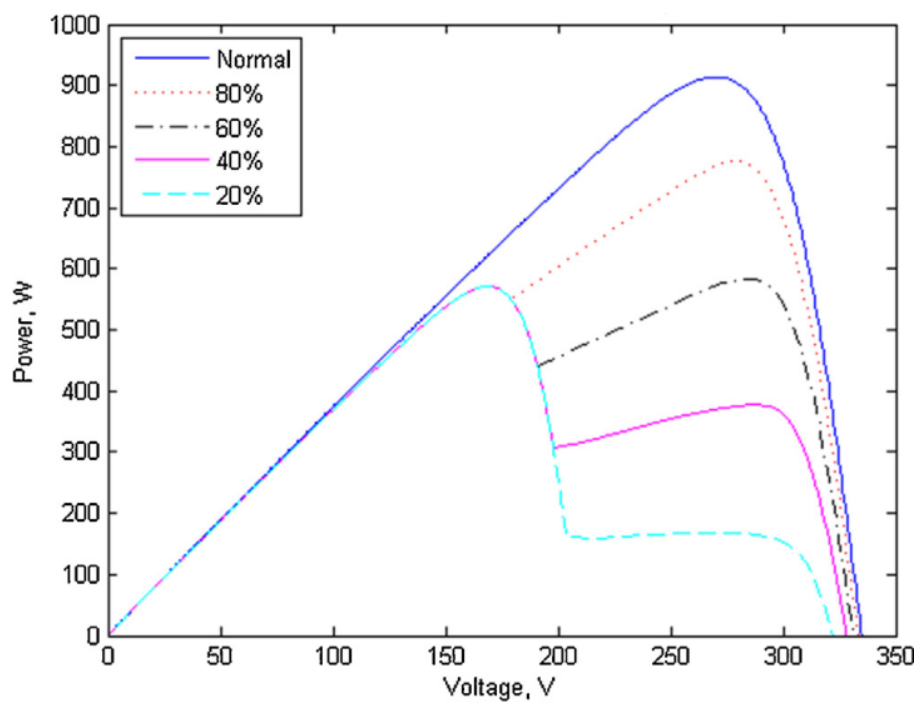

Figure 5. Effects of shading on power solar modules.

The analysis of the production of rooftop on grid solar power plant in the government building with a case study in the Setjen KESDM was intended to determine the level of production of the solar power plant built in the government building, in the form of annual, monthly, and daily values as well as the parameters that affect it. Based on the above theory, the hypothesis that can be proposed in this study is that the location of the solar power plant in a government building has an impact on the production of energy produced.

\section{Method}

\subsection{Research Design}

In analyzing the energy production of the solar power plant, there were some stages conducted by the researchers, including literature review, data collection from the field in the form of technical data, such as the kind and type of modules and inverters, slope angle of module data, module orientation, radiation values, energy production data in 2017-2019, followed by making shading model and simulation using SAM software, and finally making analysis and drawing conclusions as shown in Figure 6.

\subsection{Plant Specifications}

The solar power plant of Setjen KESDM has coordinated at $6^{\circ} 10^{\prime} 53.73$ " south latitude and $106^{\circ} 49^{\prime} 24.61^{\prime}$ " east longitude, consisting of 5 (five) placement locations, including $11^{\text {th }}$ floor rooftop, $\mathrm{T} 1, \mathrm{~T} 2, \mathrm{~T} 3$, and L carports with a total capacity of $150 \mathrm{kWp}$. The solar power plant on the $11^{\text {th }}$ floor rooftop is located on the roof of the Chairul Saleh building, while the solar power plant on the T1, T2, $\mathrm{T} 3$, and $\mathrm{L}$ rooftops are located in the office yard which functions as parking space or known as a carport.

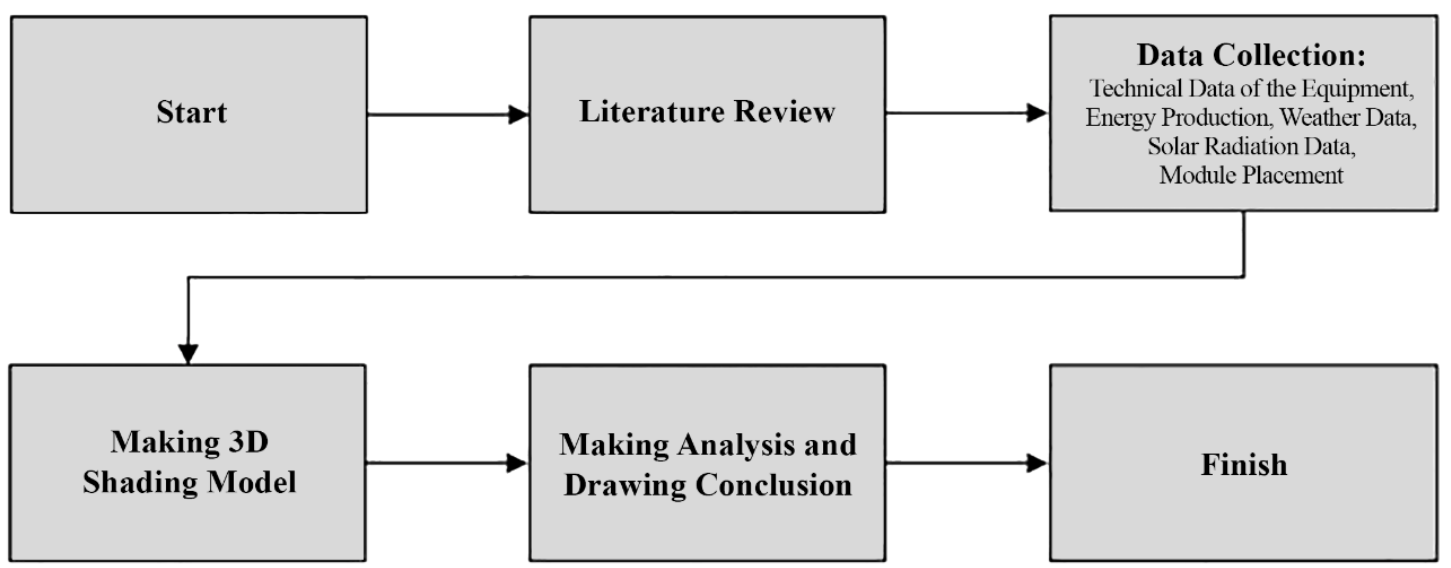

Figure 6. Flowchart of the research. 


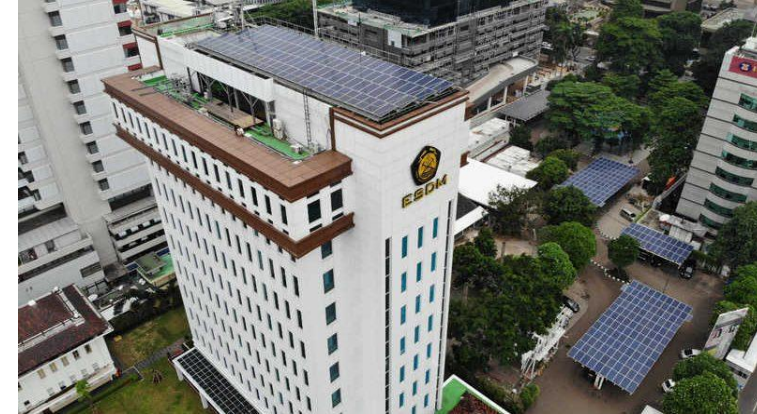

(a)

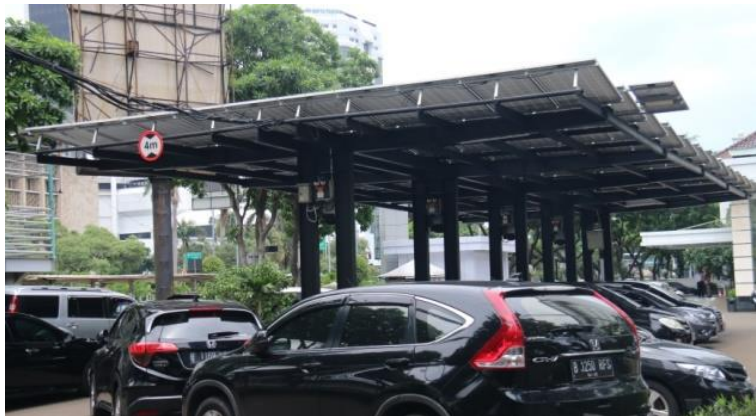

(b)

Figure 7. (a) Location of solar power plants of Setjen KESDM; (b) Installation method of solar power plants on the Setjen KESDM carport.

The solar power plants use the fixed tilt racking method, facing north to adjust with the shape of the building and the office yard of the Setjen KESDM building (Figure 7.a and 7.b). The solar power plants of Setjen KESDM are connected to the PLN network or on grid, using Jinko brand solar modules and Sunny Tripower SMA inverters.

\subsection{Instruments and Data Collection}

The solar power plants of Setjen KESDM have a monitoring system that functions to record daily, monthly, and annually data and information from the solar power plant system. The energy monitoring data was obtained from a computer communication connection to the inverter using cable or bluetooth. The data can also be monitored via the website that is used by the operator to monitor the solar power plant operations. The data recorded is in the form of energy data since the solar power plants were built, which is in 2017-2019. The solar power plant technical data is obtained by measuring and observing directly the kinds and types of equipment as shown in Table 1, Table 2, and Table 3.

Table 1. Technical data of solar power plants of Setjen KESDM.

\begin{tabular}{lccccc}
\hline \multirow{2}{*}{\multicolumn{1}{c}{ Description }} & \multicolumn{5}{c}{ Location } \\
\cline { 2 - 6 } & $\mathbf{1 1}^{\text {th }}$ Floor & T1 & T2 & T3 & L \\
\hline Number of Modules (unit) & 108 & 120 & 120 & 165 & 36 \\
\hline Module Types (Polycrystalline or Monocrystalline) & Poly & Poly & Poly & Mono & Poly \\
\hline Module Capacity $(\mathrm{Wp})$ & 315 & 315 & 315 & 180 & 315 \\
\hline Installed Capacity $(\mathrm{kWp})$ & 34.02 & 37.80 & 37.80 & 29.70 & 11.34 \\
\hline Number of Inverters (unit) & 4 & 4 & 4 & 3 & 1 \\
\hline Inverter Capacity $(\mathrm{kW})$ & 9.00 & 10.0 & 10.00 & 10.00 & 10.00 \\
\hline Total Inverter Capacity $(\mathrm{kW})$ & 36.00 & 40.00 & 40.00 & 30.00 & 10.00 \\
\hline
\end{tabular}

Table 2. Inverter specifications.

\begin{tabular}{lcc}
\hline \multirow{2}{*}{\multicolumn{1}{c}{ Characteristics }} & \multicolumn{2}{c}{ Specifications/Types } \\
\cline { 2 - 3 } & $\begin{array}{c}\text { Sunny Tripower } \\
\text { 9000TL }\end{array}$ & $\begin{array}{c}\text { Sunny Tripower } \\
\text { 10000TL }\end{array}$ \\
\hline Max. DC power (W) & 9,225 & 10,200 \\
\hline Max. input voltage (V) & 1,000 & 1,000 \\
\hline MPP voltage range/rated input voltage (V) & $370-800 / 580$ & $320-800$ \\
\hline Min. input voltage/initial input voltage (V) & $150 / 188$ & $150 / 188$ \\
\hline Max. input current per string input A/input B (Am) & $15 / 10$ & A: 22, B: $11 / 33$ \\
\hline Max. efficiency (\%) & 98.0 & 98.1 \\
\hline Rated power (@ 230 V, 50 Hz) (W) & 9,000 & 10,000 \\
\hline Max. apparent AC power (W) & 9,000 & 10,000 \\
\hline
\end{tabular}


Table 3. Module specifications.

\begin{tabular}{lcccc}
\hline \multirow{2}{*}{\multicolumn{1}{c}{ Characteristics }} & \multicolumn{3}{c}{ Specifications/Types } \\
\cline { 2 - 5 } & JKM 315PP-72 & \multicolumn{2}{c}{ JKM 180M-72 } \\
\cline { 2 - 5 } & \multicolumn{2}{c}{ Conditions } & \multicolumn{2}{c}{ Conditions } \\
\cline { 2 - 5 } & STC & NOCT & STC & NOCT \\
\hline Maximum Power (Pmax) & 315 & 234 & 180 & 134 \\
\hline Maximum Power Voltage (Vmp) & 37.2 & 34.2 & $36 \pm 0.5$ & $36 \pm 0.5$ \\
\hline Maximum Power Current (Imp) & 8.48 & 6.84 & $5 \pm 0.5$ & $5 \pm 0.5$ \\
\hline Open-circuit Voltage (Voc) & 46.2 & 43.1 & $43.2 \pm 0.5$ & $43.2 \pm 0.5$ \\
\hline Short-circuit Current (Isc) & 9.01 & 7.29 & $5.6 \pm 0.5$ & $5.6 \pm 0.5$ \\
\hline Module Efficiency STC (\%) & 16.23 & 16.23 & 17.11 & 17.11 \\
\hline Nominal operating cell temperature (NOCT) & $45 \pm 2$ & $45 \pm 2$ & $20 \pm 2$ & $20 \pm 2$ \\
\hline Irradiance (W/m ${ }^{2}$ ) & 1,000 & 800 & 1,000 & 800 \\
\hline Cell Temperature & 25 & 25 & 25 & 25 \\
\hline Ambient Temperature & 20 & 20 & 20 & 20 \\
\hline
\end{tabular}

The technical data collection of solar module installation was carried out by measurement, which obtained data in the form of module orientation facing north with the azimuth of $-2.0^{\circ}$ to $-5.0^{\circ}$ from the north and a slope angle of $9.7^{\circ}-10^{\circ}$ (Figure 8 ).

While the radiation intensity measured at the location based on an average Meteonorm is 4.7 $\mathrm{kWh} / \mathrm{m}^{2}$ with an average temperature of $26.5{ }^{\circ} \mathrm{C}$. The monthly radiation intensity and temperature distribution are shown in Table 4 [27].

Table 4. Radiation intensity and temperature data for Jakarta.

\begin{tabular}{lcc} 
Month & $\begin{array}{c}\text { GHI } \\
\left(\mathbf{W h} / \mathbf{m}^{\mathbf{2}}\right)\end{array}$ & $\begin{array}{c}\text { Ambient } \\
\text { Temperature }\left({ }^{\mathbf{}} \mathbf{C}\right)\end{array}$ \\
\hline January & 3,516 & 26.20 \\
\hline February & 3,613 & 26.00 \\
\hline March & 4,581 & 26.50 \\
\hline April & 4,742 & 26.80 \\
\hline May & 4,806 & 26.90 \\
\hline June & 4,581 & 26.50 \\
\hline July & 4,774 & 26.30 \\
\hline August & 5,387 & 26.40 \\
\hline September & 5,226 & 26.80 \\
\hline October & 5,065 & 27.10 \\
\hline November & 5,548 & 26.80 \\
\hline December & 4,290 & 26.30 \\
\hline Average & $\mathbf{4 , 6 7 7}$ & $\mathbf{2 6 . 5 5}$ \\
\hline
\end{tabular}




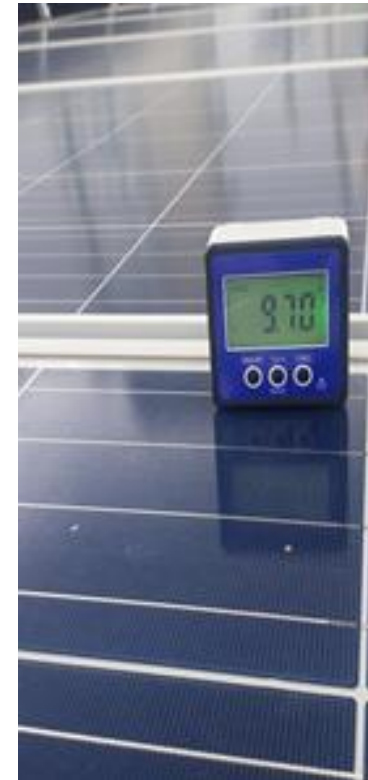

(a)

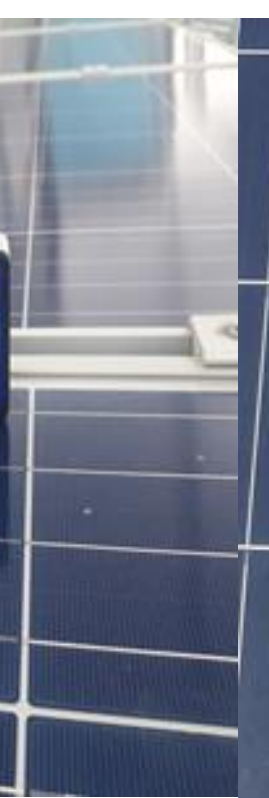

(b)

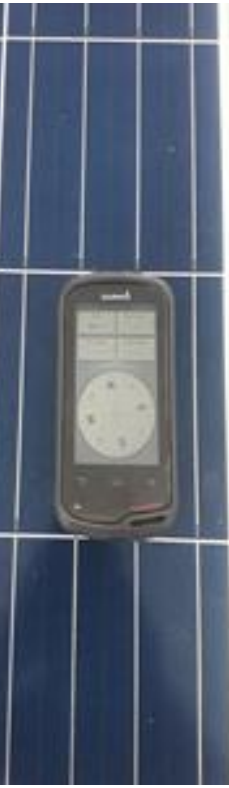

(b)

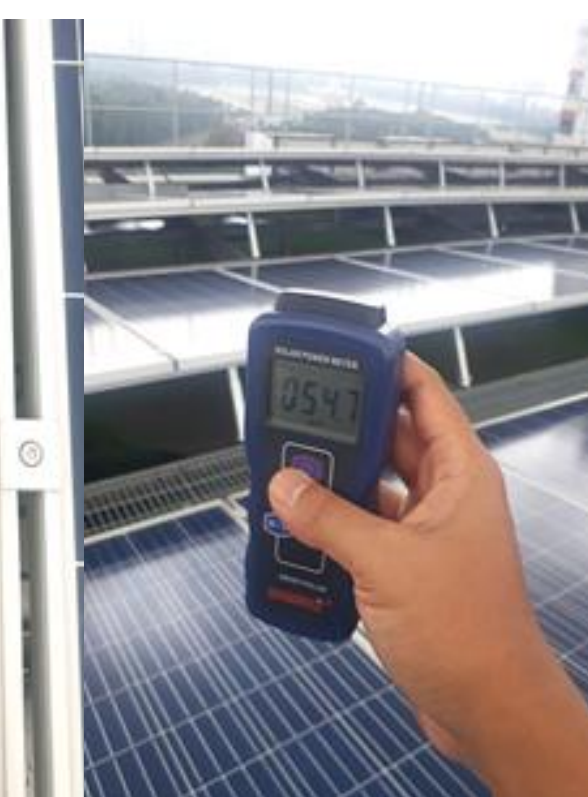

(c)

Figure 8. Data collection conditions for (a) module slope angle, (b) module orientation, and (c) radiation intensity.

\subsection{Data Analysis Method}

The data analysis was carried out by making a model following the suitability of the location and technical data by using the System Advisor Model (SAM) software (Figure 9), then performing simulation and comparing it with the real results obtained, and finally, doing the analysis.

System Advisor Model (SAM) is a software that can be used to help to model in estimating energy production from plants that use renewable energy as their energy source, including solar power plants that use solar energy. SAM can simulate the performance and financial models of a plant so that later the simulation results can be used to facilitate decision making for people involved in the renewable energy industry, such as project managers, technicians, and researchers.

The values inputted in the SAM software are location, generator orientation, module, inverter type, and solar radiation level based on location. The output produced is the amount of energy in monthly and annual. SAM can be used to determine the value of production and energy loss produced by modeling the location around the plant, which can then be known and analyzed which factors influence it.

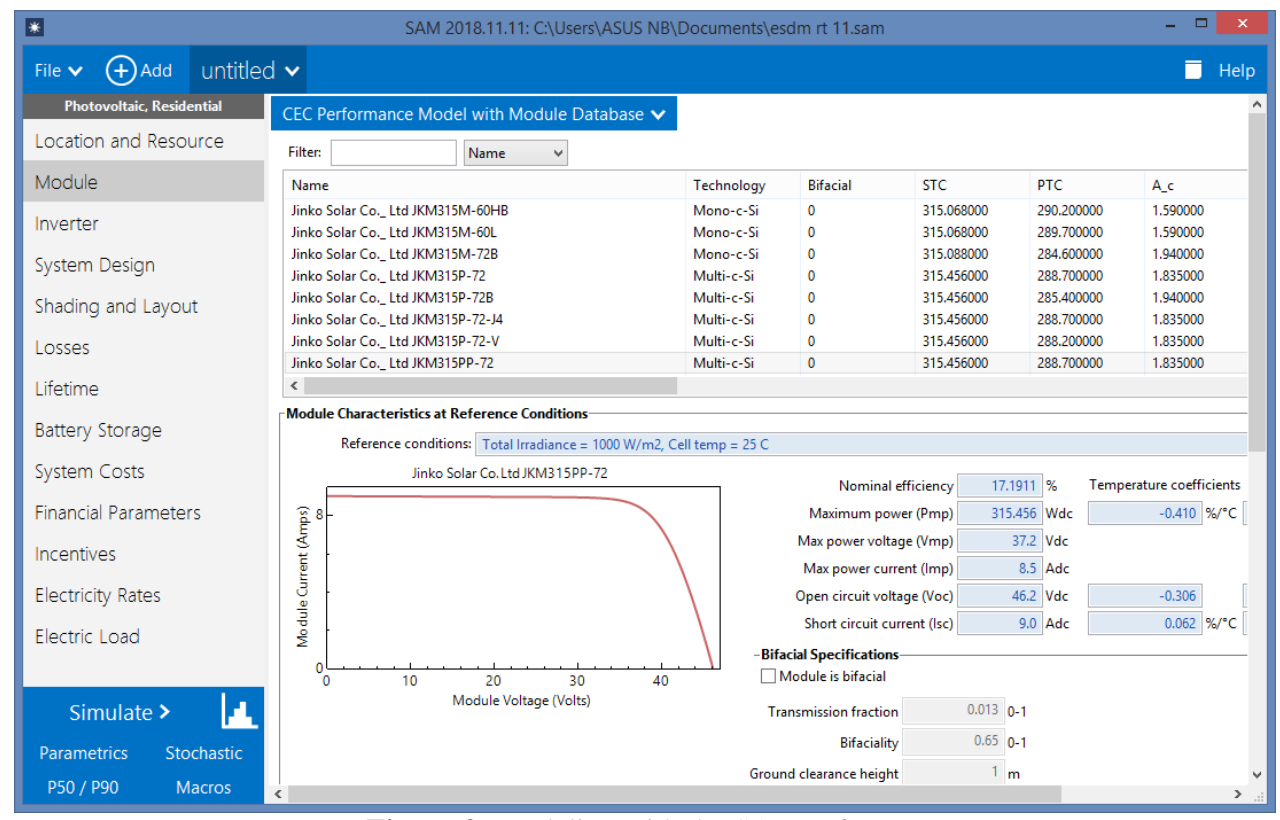

Figure 9. Modeling with the SAM software. 


\section{Result and Discussion}

The energy production of the solar power plants of Setjen KESDM was dominated by the $11^{\text {th }}$ floor rooftop compared to L, T1, T2, and T3 carports. The solar power plants of the $11^{\text {th }}$ floor rooftop with a capacity of $34.02 \mathrm{kWp}$ produced energy of $39,356.4 \mathrm{kWh}$ in $2017,42,665.7 \mathrm{kWh}$ in 2018 , and 42,674.3 $\mathrm{kWh}$ in 2019, with the more stable value produced throughout the year (Figure 10.a). The L carport of the solar power plants with a capacity of $11.34 \mathrm{kWp}$ produced energy of $12,000.3 \mathrm{kWh}$ in 2017 , $11,923.4 \mathrm{kWh}$ in 2018 , and $11,791.2 \mathrm{kWh}$ in 2019 , in which the solar power plants had a reduction in energy from November to February (Figure 10.b). The T1 carport of the solar power plants with a capacity of $37.80 \mathrm{kWp}$ produced energy of $31,073.2 \mathrm{kWh}$ in $2017,28,212.1 \mathrm{kWh}$ in 2018 , and 30,192.0 $\mathrm{kWh}$ in 2019 . The T2 carport of the solar power plants with a capacity of $37.80 \mathrm{kWp}$ produced energy of $26,958.8 \mathrm{kWh}$ in $2017,18,783.6 \mathrm{kWh}$ in 2018 , and $22,033.0 \mathrm{kWh}$ in 2019 . The solar power plants experienced a decrease in energy in June and July (Figure 10.c) (Figure 10.d). The T3 carport of the solar power plants with a capacity of $29.70 \mathrm{kWp}$ produced energy of $8,870.5 \mathrm{kWh}$ in $2017,4,733.5$ $\mathrm{kWh}$ in 2018, and 3,282.4 kWh in 2019. The solar power plants had the lowest energy output compared to others (Figure 10.e).

Based on Figure 10, it can be seen that the highest energy output was obtained in September, October, and March each year. This was due to the sun's almost perpendicular position or $90^{\circ}$ to the surface of the solar power plants so that it obtained maximum solar radiation [5]. This was supported by the fact that the location of the solar power plant of Setjen KESDM was in the $6^{\circ} 10^{\prime} 53.73$ " south latitude with the tilt angle of the module of $9.7^{\circ}-10.0^{\circ}$ facing north. The orientation and tilt position of this module is the optimal point of the solar power plants, in which its geographical location is on the equator, and can maximize the radiation received by the solar module [17]-[19].

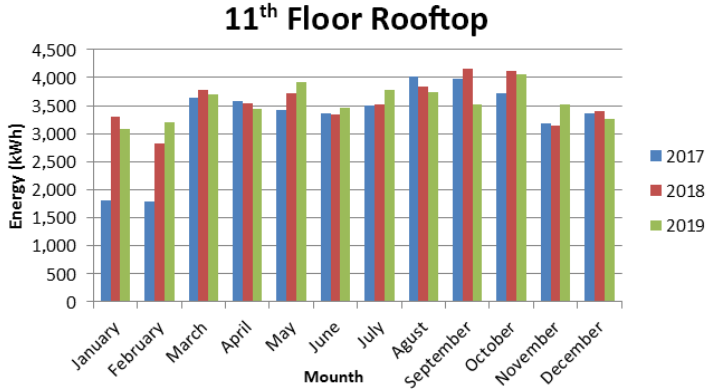

(a)

T1 Carport

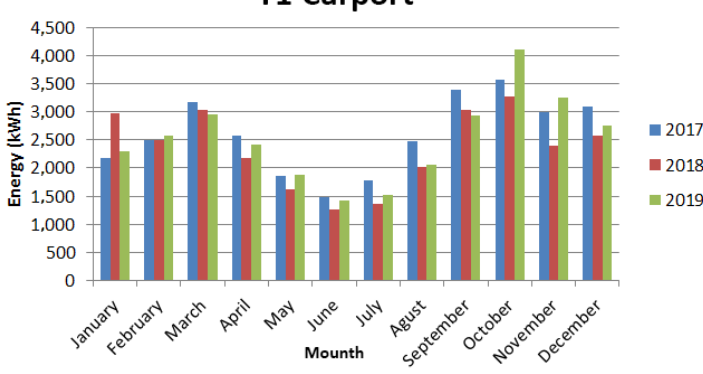

(c)

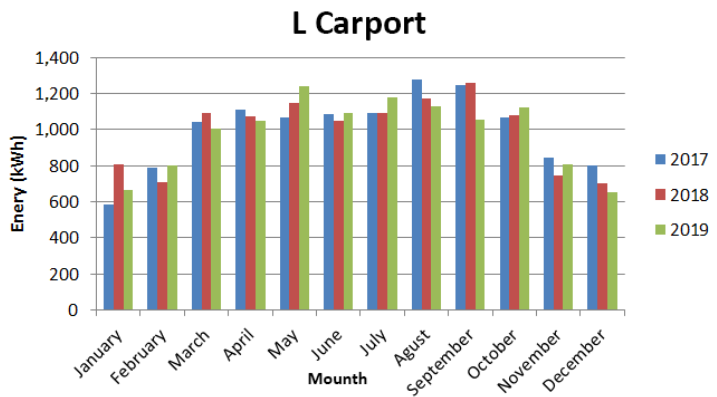

(b)

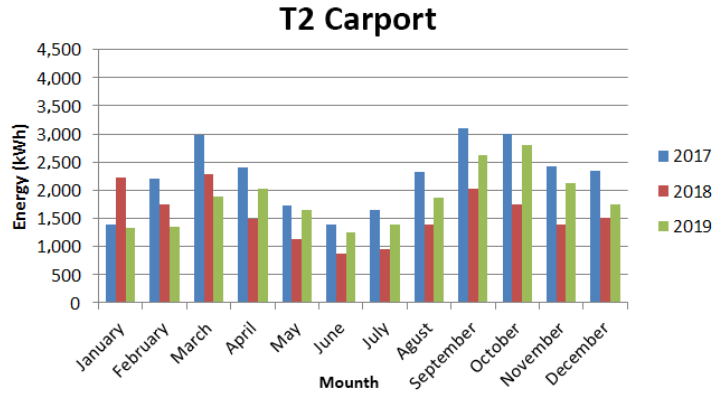

(d)

T3 Carport

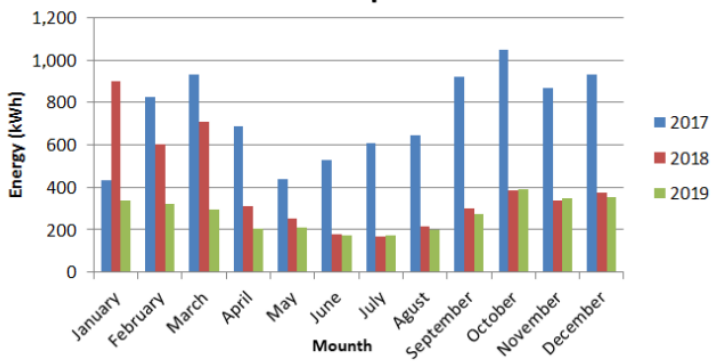

(e)

Figure 10. Graph of energy production of the solar power plants on (a) $11^{\text {th }}$ floor rooftop, (b) L carport, (c) T1 carport, (d) T2 carport, and (e) T3 carport. 
Table 5. The energy output of the solar power plants in 2017-2019

\begin{tabular}{lccccc}
\hline \multirow{2}{*}{ Month } & \multicolumn{5}{c}{ Energy (kWh) } \\
\cline { 2 - 6 } & $\mathbf{2 0 1 7}$ & $\mathbf{2 0 1 8}$ & $\mathbf{2 0 1 9}$ & $\begin{array}{c}\text { Shading } \\
\text { SAM }\end{array}$ & $\begin{array}{c}\text { Non-Shading } \\
\text { SAM }\end{array}$ \\
\hline January & $6,388.59$ & $10,222.94$ & $7,726.99$ & $9,526.88$ & $11,180.5$ \\
\hline February & $8,131.89$ & $8,375.13$ & $8,243.90$ & $9,078.89$ & $10,215.0$ \\
\hline March & $11,773.05$ & $10,908.91$ & $9,823.24$ & $10,788.89$ & $14,384.5$ \\
\hline April & $10,344.64$ & $8,596.12$ & $9,130.76$ & $10,613.87$ & $12,762.0$ \\
\hline May & $8,529.20$ & $7,856.61$ & $8,897.98$ & $9,782.95$ & $13,084.9$ \\
\hline June & $7,848.75$ & $6,698.14$ & $7,398.46$ & $8,705.30$ & $11,220.5$ \\
\hline July & $8,623.43$ & $7,085.81$ & $8,039.33$ & $10,709.10$ & $13,072.8$ \\
\hline August & $10,724.50$ & $8,635.58$ & $8,994.01$ & $11,911.33$ & $12,504.3$ \\
\hline September & $12,645.31$ & $10,767.70$ & $10,421.93$ & $13,889.20$ & $16,016.0$ \\
\hline October & $12,414.93$ & $10,592.66$ & $12,467.38$ & $13,056.24$ & $14,801.1$ \\
\hline November & $10,310.45$ & $8,026.16$ & $10,058.84$ & $11,703.13$ & $13,120.8$ \\
\hline December & $10,524.55$ & $8,552.57$ & $8,770.16$ & $10,464.25$ & $11,901.5$ \\
\hline Total & $\mathbf{1 1 8 , 2 5 9 . 2 8}$ & $\mathbf{1 0 6 , 3 1 8 . 3 2}$ & $\mathbf{1 0 9 , 9 7 2 . 9 7}$ & $\mathbf{1 3 0 , 2 3 0 . 0 3}$ & $\mathbf{1 5 4 , 2 6 4 . 1}$ \\
\hline
\end{tabular}

There are main factors that influence the energy output of the solar power plants of Setjen KESDM, which are radiation and shading. Based on simulations using SAM software, the total energy produced by the solar power plants of Setjen KESDM compared to real energy is as shown in Table 5 .

The highest monthly energy output of the real and simulation was obtained in September, October, and March each year, while the output value without shading showed the maximum energy value that could be produced by the solar power plants. The shading had a significant impact on the energy production of solar power plants. The reduction in energy production is in line with the area experiencing shading and the reduction in solar radiation, the decrease in power at the module or array level is often far from linearity with the part experiencing shading [20], [22], [23].

The shading gave energy losses to the output of the solar power plants. Based on simulations using SAM software, the $11^{\text {th }}$ floor rooftop of the solar power plants did not experience energy losses due to shading. In contrast, the L carport of the solar power plants experienced energy losses of 4,094.4 $\mathrm{kWh}$ or $25.59 \%$ of the maximum energy that could be produced, the T1 carport of the solar power plants of $23,505.3 \mathrm{kWh}$ or $44.07 \%$, the T2 carport of the solar power plants of $30,729.3 \mathrm{kWh}$ or $57.64 \%$, and the T3 carport of the solar power plants of $36,274.6 \mathrm{kWh}$ or $86.57 \%$.

Shading can be in the form of trees, buildings, clouds, leaf litter, or solar modules installed nearby [20], [21]. At the solar power plants of Setjen KESDM, there is shading caused by the shadow of buildings and trees. The $11^{\text {th }}$ floor rooftop of the solar power plants did not get shading of trees and buildings because it is located on the $11^{\text {th }}$ floor of Chaerul Saleh building (Figure 11.a). The L carport of the solar power plants received the Indosurya Center building shading that occurred in the afternoon until the afternoon when the sun's position was in the southern part of the equator in October-February (Figure 11.b). The T1 carport of the solar power plants received the Chaerul Saleh building shading in the morning when the sun's position was in the northern part of the earth in April-August (Figure 11.c). The T2 carport of the solar power plants received the Jakarta Box Tower building shading in the morning and the Indosurya Center building shading in the afternoon when the sun's position was in the southern hemisphere or on November-February (Figure 11.d). The T3 carport of the solar power plants received the Jakarta Box Tower shading in the morning to noon, while the afternoon radiation was blocked by trees around the solar power plant (Figure 11.e). 


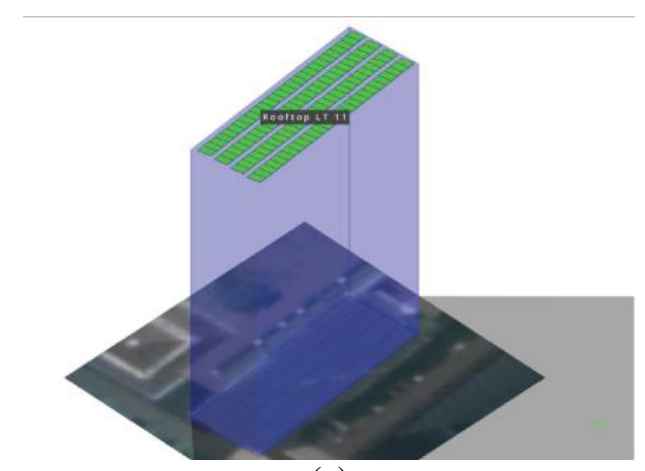

(a)

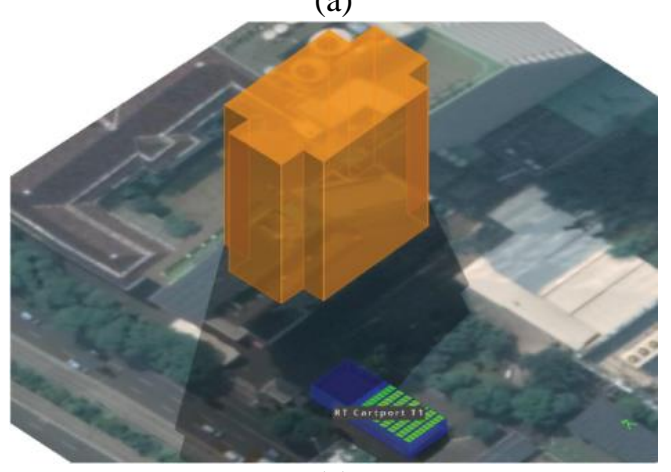

(c)

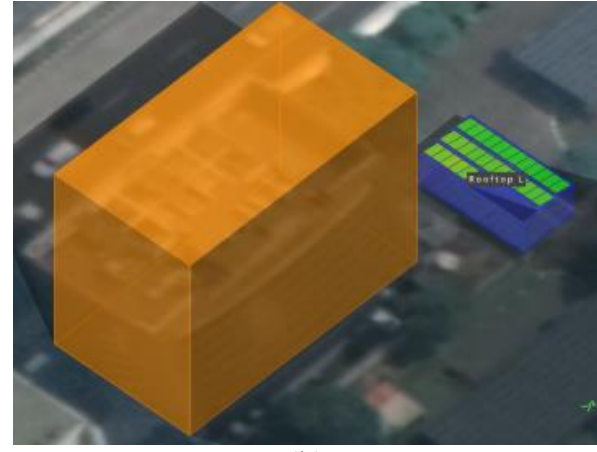

(b)

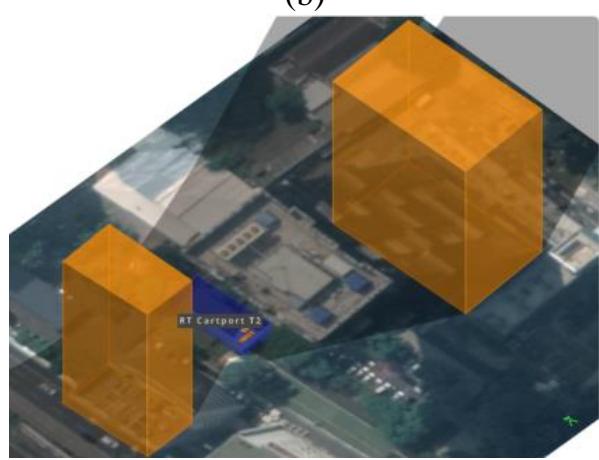

(d)

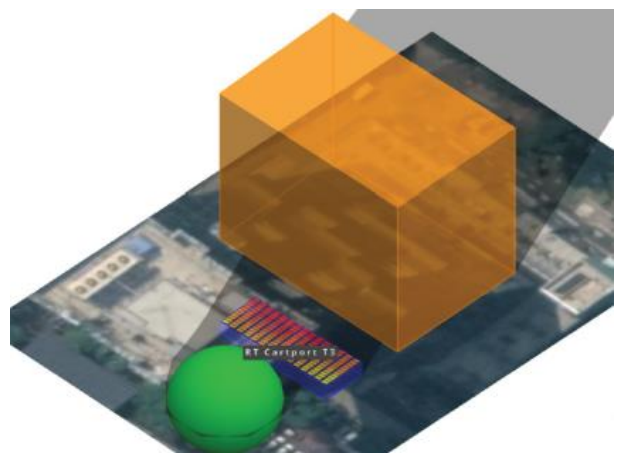

(e)

Figure 11. Display of 3D shading of the solar power plants of Setjen KESDM.

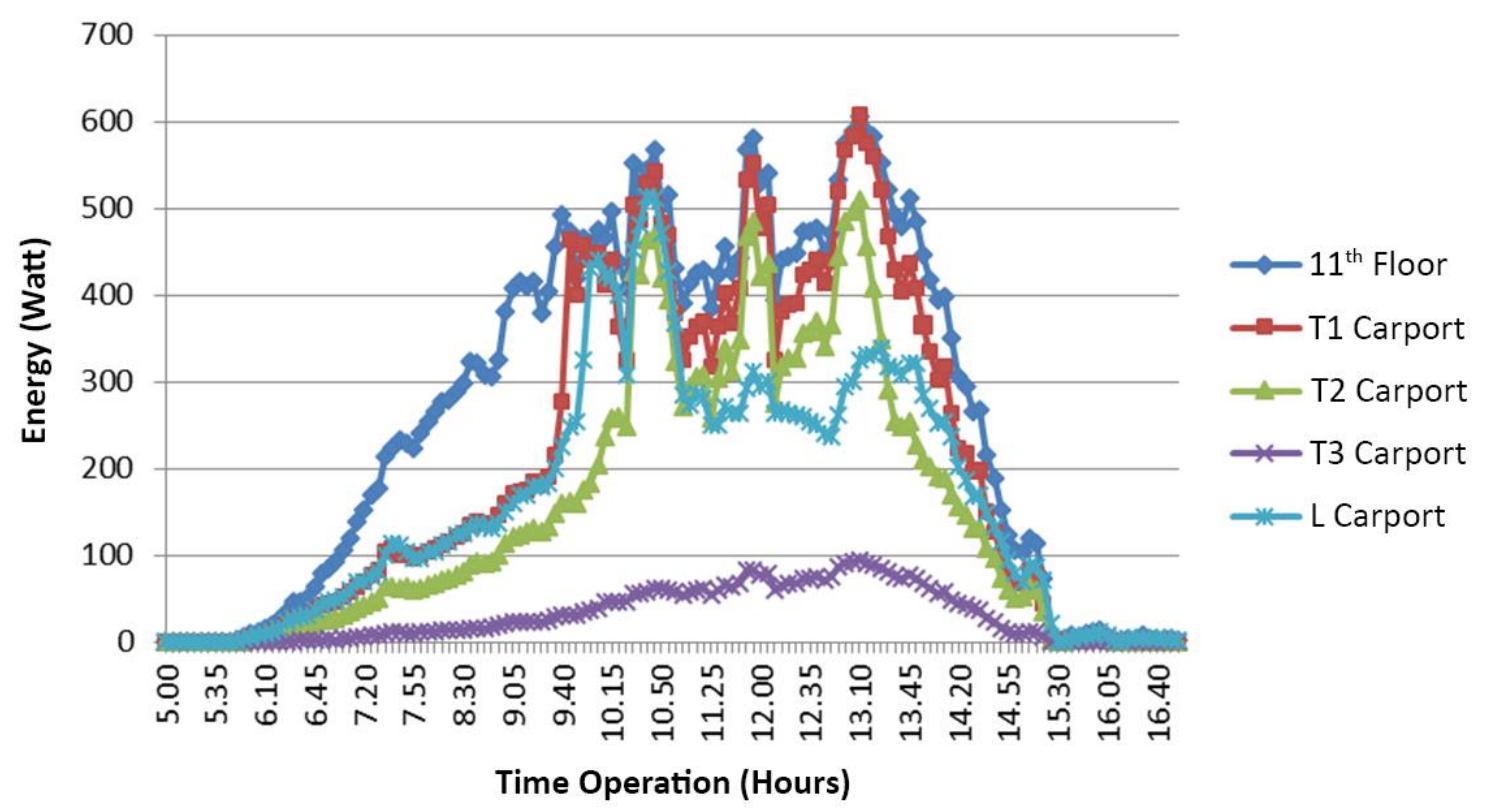

Figure 12. Graph of PLTS daily energy on December 22, 2019. 
The effect of shading based on daily energy measurements can be seen based on normalized energy data of $1 \mathrm{~kW}$ per hour each on the sun's position on December 22, 2019 (Figure 12). The 11 ${ }^{\text {th }}$ floor rooftop of the solar power plants produced energy with the significant value from sunrise to sunset. While the T1, T2, and L carport of the solar power plants experienced an increase in maximum energy starting at 9.30 AM and some solar power plants experienced a decrease in energy starting at $01.10 \mathrm{PM}$. The T3 carport of the solar power plants was not maximal in producing energy, in which it only reached a maximum value at $12.00 \mathrm{PM}$. This is caused in the morning and evening, the buildings around the solar power plants gave shading to the surface of the solar power plant modules of the L, T1, T2, and T3 carports (Figure 11).

A solar module will work best under Standard Test Conditions (STC), in which the solar radiation is $1,000 \mathrm{~W} / \mathrm{m}^{2}$, wind speed is about $1 \mathrm{~m} / \mathrm{s}$ (air mass of 1.5 ), and the ambient temperature is $25^{\circ} \mathrm{C}$. The higher the ambient temperature around the solar panel, the less electrical power produced [9], [10]. The level of ambient temperature in the location of the solar power plants of Setjen KESDM was higher than the standard conditions, as shown in Table 4, so that the real energy production could not reach the maximum point.

\section{Conclusion}

Solar radiation and shading are the main factors that influence the solar power plant output. The highest energy output was obtained in September, October, and March each year, because in those months the sun is almost in the perpendicular position or $90^{\circ}$ to the solar power plant surface, while shading caused energy losses to solar power plants. Based on the simulations using SAM software, the $11^{\text {th }}$ floor rooftop of the solar power plants did not experience energy losses due to shading. In contrast, the L carport of the solar power plants experienced energy losses of $4,094.4 \mathrm{kWh}$ or $25.59 \%$ of the maximum energy that could be produced, the T1 carport of the solar power plants of $23,505.3 \mathrm{kWh}$ or $44.07 \%$, the T2 carport of the solar power plants of $30,729.3 \mathrm{kWh}$ or $57.64 \%$, and the T3 carport of the solar power plants of $36,274.6 \mathrm{kWh}$ or $86.57 \%$. The optimal placement for the solar power plants of government buildings is on the rooftop of the building because it is free from the tree and building shading.

\section{Acknowledgment}

The author would like to thank the Government of Riau Province for the support of research funding as well as the Secretariat General of Energy and Mineral Resources Ministry for valuable data provided.

\section{References}

[1] J. Widodo, "Rencana Umum Energi Nasional Republik Indonesia" in Peraturan Presiden Republik Indonesia Nomor 22 Tahun 2017, Jakarta: Kementerian Sekretariat Negara, 2017.

[2] H. Asrofi, "Penggunaan Sistem Pembangkit Listrik Tenaga Surya Atap oleh Konsumen PT Perusahaan Listrik Negara (Persero)," in Peraturan Menteri ESDM Nomor 49 Tahun 2018, Jakarta: Kementerian Energi dan Sumber Daya Mineral, 2018.

[3] S. Hamdi, "Mengenal Lama Penyinaran Matahari sebagai Salah Satu Parameter Klimatologi, Peneliti Pusat Sains dan Teknologi Atmosfer," Berita Dirgantara Lapan, vol. 15, no. 1, pp. $7-$ 15, 2014.

[4] I. K. A. Setiawan, W. Sukerayasa, and I. N. S. Kumara, "Analisis Unjuk Kerja Pembangkit Listrik Tenaga Surya (PLTS) Satu MWP Terinterkoneksi Jaringan di Kayubihi,” Majalah Ilmiah Tekno. Elek., vol. 13, no. 1, 2014.

[5] B. Rosengren, Technical Application Papers No. 10 Photovoltaic Plants, Zürich: ABB Group, 2010.

[6] J. A. Duffie and W. A. Beckman, Solar Engineering of Thermal Processes, 4th ed., Madison: Wiley, 2013.

[7] V. Quaschning, Understanding Renewable Energy System, London: Earthscan, 2012.

[8] E. T. Hashim and A. A. Abbood, "Temperature Effect on Power Drop of Different Photovoltaic Modules," J. Eng., vol. 22, no. 5, pp. 129-143, 2016.

[9] N. O. Arinze and M. E. Farrag, "Analysis of PV Modules Performance in Nigeria: A Guide for Suitable System Design and Module Specifications Selection," Int. J. Research Eng. and Sci. (IJRES), vol. 6, no. 7, pp. 01-13, 2018. 
[10] K. H. Khwee, "Pengaruh Temperatur terhadap Kapasitas Daya Panel Surya (Studi Kasus: Pontianak)," J. Tek. Elek. ELKHA, vol. 5, no. 2, pp. 23-26, 2013.

[11] J. Adeeb, A. Farhan, and A. Al-Salaymeh, "Temperature Effect on Performance of Different Solar Cell Technologies,” J. Ecol. Eng., vol. 20, no. 5, pp. 249-254, 2019.

[12] Q. M. Aish, "Temperature Effect on Photovoltaic Modules Power Drop," Al-Khwarizmi Eng. J., vol. 11, no. 2, pp. 62-73, 2015.

[13] J. A. del-Cueto, PV Module Energy Ratings Part II: Feasibility of Using the PERT in Deriving Photovoltaic Module Energy Ratings, Golden: National Renewable Energy Laboratory, 2007.

[14] D. Myers, "Evaluation of the Performance of the PVUSA Rating Methodology Applied to Dual Junction PV Technology," in Ameri. Solar Energy Society Ann. Conf., New York: National Renewable Energy Laboratory, pp. 1-11, 2009.

[15] S. Dubey, J. N. Sarvaiya, and B. Seshadri, "Temperature Dependent Photovoltaic (PV) Efficiency and Its Effect on PV Production in the World - A Review," Energy Procedia, vol. 33, pp. 311$321,2013$.

[16] J. Amajama and S. E. Mopta, "Effect of Air temperature on the Output of Photovoltaic Panels and Its Relationship with Solar Illuminance/Intensity," Int. J. Sci. Eng. App. Sci. (IJSEAS), vol. 2, no. 8, pp. 161-166, 2016.

[17] E. A. Handoyo, D. Ichsani, and Prabowo, "The Optimal Tilt Angle of A Solar Collector," Energy Procedia, vol. 32, pp. 166-175, 2013.

[18] A. Rachman, "Optimalisasi Teknologi Energi Surya Berbasis Penyesuaian Posisi Panel Bulanan di Sulawesi Tenggara," J. Tekno., vol. 8, no. 1, pp. 1-8, 2016.

[19] Y. S. Khoo et al., "Optimal Orientation and Tilt Angle for Maximizing In-Plane Solar Irradiation for PV Applications in Singapore," IEEE J. Photovoltaics, vol. 4, no. 2, pp. 647-653, 2014.

[20] E. E. Ekpenyong and F. I. Anyasi, "Effect of Shading on Photovoltaic Cell," IOSR J. Elec. Electro. Eng., vol. 8, no. 2, pp. 1-6, 2013.

[21] A. Djalab et al., "Study of the Effects of Partial Shading on PV Array," in Int. Conf. Comp. Elect. Eng. (ICCEE), Tokyo: ICCEE, pp. 1-5, 2018.

[22] F. Salem and M. A. Awadallah, "Detection and Assessment of Partial Shading in Photovoltaic Arrays," J. Elec. Sys. Info. Techno., vol. 3, no. 1, pp. 23-32, 2016.

[23] J. C. Teo et al., "Impact of Partial Shading on the P-V Characteristics and the Maximum Power of A Photovoltaic String," Energies, vol. 11, no. 7, p. 1860, 2018. 